\section{Colombian jailed for defending human rights}

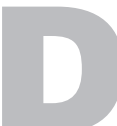

avid Rabelo Crespo, a Colombian human rights leader, was jailed on 14th September 2010. He has been imprisoned since without being convicted of any crime. He is currently held in La Modelo Prison, Bucaramanga, falsely accused of 'conspiracy to commit a crime' and 'aggravated homicide'. The evidence against him is based on former paramilitary witnesses, who receive benefits from the Colombian state in exchange for their testimony.

Specifically, Mr Rabelo's case hinges on evidence from imprisoned paramilitary 'El Panadero'. His testimony, given under the Uribe administration's Justice and Peace Law, allowed him to reduce his prison sentence from over 40 years to a maximum of eight.

Colombian human rights groups have criticised the law as it provides no penalties for false information and as a result such testimony has been used in numerous cases against government critics. Even more worrying is that 'El Panadero' is imprisoned as a direct result of $\mathrm{Mr}$ Rabelo's human rights work, which played a leading role in uncovering the abuses he committed. It is for this reason that Mr Rabelo claims the case against him is driven by paramilitary interests.

Mr Rabelo is the national spokesperson for Credhos, the regional corporation for human rights, and a leading member of the national human rights

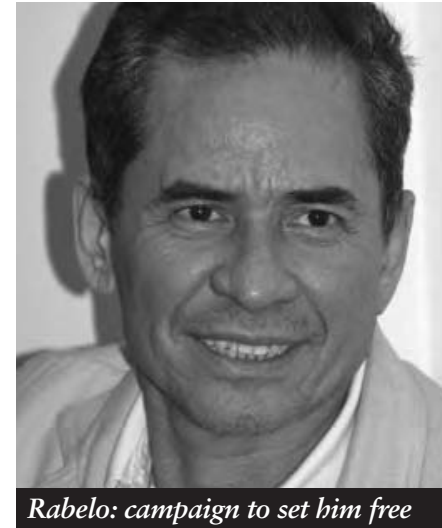

coalition MOVICE, the Movement for Victims of State Crimes, one of the largest and most persecuted organisations in Colombia. On 9th January 2012 The Haldane Society adopted a campaign for Mr Rabelo's release and for the defence of his organisation MOVICE, in response to the threats they face.

Just before going to print, we learnt of the disappearance of Fernando Riascos, member of
MOVICE Cundinamarca, and his five year old daughter on 13th January 2012. Mr Riascos had been unwavering in his calls for justice for the death of his wife, Zenaida Leguizamón, shot by members of the Colombian army in 2008 .

Mr Rabelo has dedicated his life to speaking out against human rights violations. He is just one of so many who have faced false accusations, imprisonment, death threats and assassinations as a result of their work. The majority of those targeted are members of civil society opposition, among them trade unionists, human rights defenders, peasant farmers, academics, student and indigenous leaders.

The 2010 election of President Juan Manuel Santos has brought about a significant change in rhetoric and claims of an increased commitment to human rights.

However, with 24 trade unionists assassinated in 2011, Colombia continues to be the most dangerous country in the world

\title{
The dangers behind the proposed judicial reform in
}

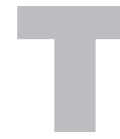

he judicial reform bill, currently being debated in the Colombian congress, threatens to compromise the relative independence that the country's courts have enjoyed since the passage of the 1991 Constitution. This independence has allowed Colombia to investigate more than 60 members of congress for charges of collaborating with narco-traffickers and paramilitaries. It enabled the courts to declare over the last two years that both the establishment of US military bases on Colombian soil and Álvaro Uribe Vélez's (20022010) third-term presidential bid were unconstitutional.

Because of these and many other cases, the Colombian executive and congress have been placed in an embarrassing position, tarnishing their legitimacy. The courts have become the only protector of the democratic process and its constitutional underpinning.

The current judicial reform comes within this context in an attempt to restrict the jurisdiction of the courts to investigate and convict members of congress that is enshrined in the 1991 Constitution. The judicial reform is also a push to protect the military from the jurisdiction of the civil courts, as the military expands the role of military tribunals.

These and other aspects of the reform are troubling for a

\section{January}

17: The European Court of Human Rights grants the appeal of the Jordanian cleric Abu Qatada against deportation. The court ruled that he would be unlikely to receive a fair trial were he deported because torturetainted evidence would be used against him.
17: Legal and constitutional expert Prime Minister David Cameron continues his attack against the European Court of Human Rights. In a speech to the Council of Europe, Cameron said the court was in danger of only dealing with 'small claims'.
27: Sir Nicholas Bratza, the British President of the European Court of Human Rights warns senior politicians against using 'emotion and exaggeration' to criticise the court. In an article in The Independent, Bratza responded to increasing hostility from Tory frontbenchers. country like Colombia where the institutions have been heavily penetrated by narcotraffickers and their armed militias - particularly the Colombian congress and the military. For the consolidation of the country's democracy it is important for the Supreme Court to continue to have the jurisdiction to investigate and sentence members of congress, and for the civil courts to be expanded in order to prosecute military personnel who commit

\section{February}

1: Julian Assange's appeal against his extradition begins in the Supreme

Court. Assange hopes to persuade the seven judges hearing the case that Swedish prosecutors are not entitled to issue arrest warrants as they cannot be considered a 'judicial authority'. 
for union members and human rights groups report ongoing threats against their work on the ground; David Rabelo's drawn out detention is testament to that.

Human rights violations in Colombia take place under the pretext of a conflict that has raged for over 40 years, between the Colombian army, right-wing paramilitaries and left-wing guerrillas. However, civilians have been targeted disproportionately, in part as a result of the army's indiscriminate counter-insurgency strategy, which according to Amnesty International is 'largely based on the premise that those living in conflict areas are part of the enemy'.

Colombian civil society is calling for a solution to the conflict, to help end the abuses. The UK NGO Justice for Colombia has launched a Peace Campaign in response. For more information on how to support Justice for Colombia's work please visit www.justiceforcolombia.org Natasha Morgan

\section{Colombia}

crimes against civilians, as well as war crimes. Knowing the human rights violations record of the Colombian police and army these two must be kept under greater scrutiny if good governance is desired.

\section{Nazih Richani}

Nazih is Associate Professor of Political Science and Director of Latin American studies at Kean University in Union, New Jersey. This article first appeared on the NACLA website on 27th

December 2011

3: A clandestine operation that secretly deployed police spies (including Mark Kennedy) in political groups for 40 years is severely criticised by an official policing inspectorate. It concludes the 'intrusive' tactic should in future be used only after independent authorisation'; and found serious failings by the National Public Order Intelligence Unit(NPOIU). $\mathrm{n}$ the second week of January 2012 the Legal Aid, Sentencing and Punishment of Offenders Bill resumed its passage through the House of Lords. Carefully timed to coincide with this, the New Year also saw the publication of Unintended Consequences: the Cost of the Government's Legal Aid Reforms. The report, authored by $\mathrm{Dr}$ Graham Cookson of King's College, aims to do what the Government has thus far failed to do, and quantify the knock-on costs of the legal aid cuts.

The report makes for interesting, though perhaps not surprising reading. Among its headlines, Cookson indicates that the cuts will save in the region of $£ 139$ million per annum, 'realising a net saving of significantly less than half ( 42 per cent) of the Government's prediction'. He qualifies this with the rider that 'numerous costs could not be estimated, and this figure is therefore likely to be a substantial underestimate of the true costs'. The cuts to legal aid for social welfare law will, he estimates, generate a further $£ 35$ million in knock-on costs, equating to a net saving of 39 per cent, while, shockingly, the cuts to clinical negligence will generate a net loss of $£ 18$ million.

The logic underpinning Cookson's findings is easy to see: by providing legal advice early on to help resolve debt issues, employment disputes or appeal a wrongful refusal of welfare benefits, there is less chance that the original problem will escalate and increase costs for the taxpayer. Cookson's findings also correspond with earlier research carried out by Citizens Advice and by the New Economics

Foundation on behalf of the Law Centres Federation.

The Government's attitude toward this body of research has been consistently dismissive. In response to Citizens Advice and the Law Centres Federation the Government cited 'reservations about the methodology employed'. Such responses fall short of the mark. The Government's impact assessments bleakly acknowledge that 'legal aid recipients are amongst the most disadvantaged in society' and that the cuts 'have the potential to impact a greater proportion of women, Black, Asian and Minority Ethnic people, and ill or disabled people'. The Government case has always been that this is justified, as 'a proportionate means of meeting our legitimate policy objectives'. If the cuts do not save money then the political and moral case for cutting legal aid falls away.

In the circumstances one would be forgiven for thinking that the cuts are driven by ideology rather than necessity, a sentiment born out in the Government's criticism that the legal aid scheme 'bears little resemblance to the one introduced in 1949, having expanded far beyond its original scope'. This argument - that the welfare state must be cut back to 'first principles' - is one that is gaining currency in varying contexts across the political spectrum. Such arguments are also inaccurate. In the report which presaged the Legal Advice and Assistance Act 1949 Lord Rushcliffe envisioned a system where legal aid would be available 'in all courts and in such manner as will enable persons in need to have access to the professional help they require' and not be limited to those who are 'normally classed as poor' but should include 'those of small or moderate means'. To intimate that legal aid currently does more than this is simply wrong.

It is against this backdrop that the Bill Committee of the House of Lords has been urging the Government to return to the drawing board before proceeding with the legal aid cuts. An amendment tabled to the Legal Aid Bill which would have required the Government to properly assess the impact of the cuts on vulnerable groups attracted widespread support. Lord Pannick QC, speaking out in support of the amendment, criticised what he described as the twin factual premises of the Bill - that it will save large amounts of public money and that it will not damage access to justice for vulnerable groups labelling them as 'highly contentious' and 'assertion rather than evidence'. Though the amendment was withdrawn, the support that it garnered was encouraging. Lord Bach, summing up before withdrawing the amendment, spoke out against the 'false argument' that life and liberty are the only values which warrant protecting through legal aid: 'it is difficult to think of a more obvious place where legal aid is appropriate than to solve legal problems that affect people who are, through no fault of their own, poor or disabled or who lack any privileges.

What the early weeks of 2012 have shown is that the House of Lords stage of the legislative process provides a real chance to change the Legal Aid Bill for the better and that the need to do so is as pressing as it has ever been. The committee debates will continue until February 2012 followed by the all-important report stage. Please sign up to the Justice for All 'pair up with a peer' scheme at www.justice-for-all.org.uk

In the last issue, writing on the riots, I commented that Labour Councillors were not around in Hackney on the evening of the riots. They were around and doing their bit to check residents were OK. Apologies.

\section{- Connor Johnston is a}

member of Young Legal Aid

Lawyers and a pupil barrister at Garden Court Chambers

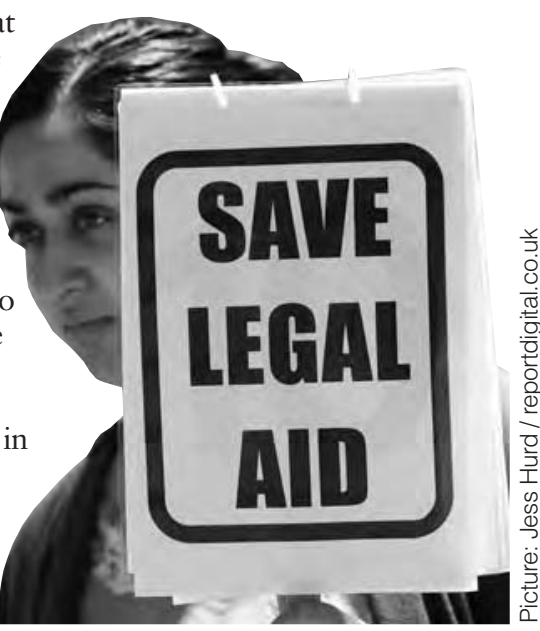

